\title{
REFERENCES
}

1. Metodicheskie ukazaniya dlya vokalnikh fakultetov muzikalnikh vuzov "Pedagogicheskaya praktika", Sost. M.S. Agikyan. M.: GMGII im. Gnesinykh, 1983. 66 s.

2. Metodologicheskie problemi muzykalnoy pedagogiki: Materialy mezhrespublikanskoy nauchnoprakticheskoy konferentsii. M., 1991. 124 s.

3. Medushevskiy V.V. Uglublyat kontseptsiyu muzikalnogo obrazovaniya // Sov. muzyka. 1981. № 9. S. 52-59.

4. Problemy kompleksnogo tvorcheskogo vospitaniya muzykanta-ispolnitelya (shkola - uchilishche vuz). Sb. trudov. Novosibirsk, 1984. 149 s.

5. Razhnikov V.G. Rezervy muzykalnoy pedagogiki. M.,1980. 95 s.

УДК 782.087.68

DOI https://doi.org/10.31723/2524-0447-2020-30-1-18

\author{
Олена Миколаӥвна Батовська \\ ORCID: 0000-0002-1435-1245 \\ кандидат мистецтвознавства, доцент, \\ доцент кафедри хорового диригування \\ Харківського національного університету мистецтв \\ імені I. П. Котляревського \\ bathelen@ukr.net
}

\section{ТРАКТУВАННЯ ХОРУ В ОПЕРІ-КАЗЦІ «ЧАРІВНА ФЛЕЙТА» В. А. МОЦАРТА}

Мета роботи полягає у виявленні особливостей трактування хору в опері-казці «Чарівна флейта» B.A. Моцарта, що сприяє утворенню цілісної картини щодо трактування хору в оперних творах композитора. Методологія дослідження становить поєднання методів цілісного, інтонаційного, жсанрово-стильового, композиційного, драматургічного аналізів. Наукова новизна представленої роботи виявляється в таких аспектах: уперше у вітчизняному мистецтвознавстві здійснено комплексно-аналітичний аналіз із позиції специфіки трактування хору в опері-казці «Чарівна флейта» В.А. Моцарта; доводиться вплив жанрових ознак на трактування хору в опері. Висновки. В опері «Чарівна флейта» В.А. Моиарт активно використовує хор. Провідними функціями хору в опері «Чарівна флейта» $\epsilon$ : фоновоілюстративна, репрезентативна і репрезентативно-динамічна. Аналіз хорових номерів в опері «Чарівна флейта» показав, що на їх трактування вплинула жанрова природа твору. Хору в опері «Чарівна флейта» композитор відвів роль відтворення царства чарівника Зарастро. Тому протягом усієї опери поява хору є своєрідним лейтмотивом цього казкового світу. Хори вимальовують загальну атмосферу дії й опосередковано причетні до подій, що відбуваються. Елементи зингшпілю дають про себе знати у використанні розмовних діалогів і народних пісень із куплетною будовою, у пісенно-танцювальних елементах музичної лексики. Водночас простежсуєься зв'язок твору з оперою-sеria. Про ие свідчать серйозність проблематики, символістична трактовка персонажсів, використання арій-амплуа (передусім Цариці Ночі). Отже, у «Чарівній флейті» сплелись жсанрові особливості зингшпілю, опери-bиffa й опери-sеria. У даній опері простежуються ораторіальні і містеріальні риси в синтезі з оперними засадами та витоками австрійського зингшпілю.

Ключові слова: опера-казка «Чарівна флейта» В.А. Моцарта, трактування хору.

Batovska Olena Mykolaivna, PhD in Arts, Associate Professor, Associate Professor at the Choral Conducting Chair of the Kharkiv National I. P. Kotlyarevsky University of Arts

The interpretation of the chorus in the fairy tale-opera "The Magic Flute" by W. A. Mozart

Research objective is to identify the specificity of the chorus interpretation in the fairy tale-opera "The Magic Flute" by W.A. Mozart, which contributes to the formation of a holistic picture regarding the interpretation of the choir in the opera works of the composer. The methodology of the research is the combination of methods of holistic, intonational, genre-style, compositional, dramatic analysis. The scientific novelty of the presented research consists in the following aspects: for the first time in the national art criticism a complex analytical analysis was made from the standpoint of the specificity of the choir's interpretation in the fairy tale-opera "The Magic Flute" by W.A. Mozart; the influence of genre signs on the interpretation of the choir in the opera is proved. Conclusions. In the opera "The Magic Flute" by W.A. Mozart actively uses the choir. In general, in 
"The Magic Flute" the choir plays the role of events accompaniment. The main functions of the choir in the opera "The Magic Flute" are: background-illustrative, representative and representative-dynamic functions. The analysis of the choral acts in the opera "The Magic Flute" showed that their interpretation was influenced by the genre nature of the work. In the opera The Magic Flute, the composer assigned the chorus the role of reflecting the kingdom of the wizard Zarastro. Therefore, throughout the opera, the appearance of the choir is a kind of leitmotif of this fairy-tale world. Choirs outline the general atmosphere of action and are indirectly related to events. Singspiel elements make themselves felt in the use of conversational dialogues and folk songs with a couplet structure, in song and dance elements of musical vocabulary. At the same time, the connection of the work with opera-seria is traced. This is evidenced by the seriousness of the problems, the symbolic interpretation of the characters, the use of Aryan roles (primarily the Queen of the Night). Thus, in this opera, oratorioral and mystery features are traced in the synthesis with the opera principles and origins of the Austrian singspiel

Key words: fairy tale-opera "Magic Flute by W.A. Mozart, interpretation of choir.

Батовская Елена Николаевна, кандидат искусствоведения, доцент, доцент кафедры хорового дирижирования Харьковского национального университета искусств имени И. П. Котляревского

\section{Трактовка хора в опере-сказке «Волшебная флейта» В. А. Моцарта}

Цель работы состоит в выявлении особенностей трактовки хора в опере-сказке «Волшебная флейта» В.А. Моцарта, что способствует образованию иелостной картины относительно трактовки хора в оперных произведениях композитора. Методология исследования заключается в сочетании методов целостного, интонационного, жеанрово-стилевого, композиционного, драматургического анализов. Научная новизна представленной работы выражается в том, что впервые в отечественном искусствоведении осуществлен комплексно-аналитический анализ с позиции специфики трактовки хора в опере-сказке «Волшебная флейта» В.А. Моцарта; доказывается влияние жканровых признаков на трактовку хора в опере. Выводы. В опере «Волшебная флейта» В.А. Моцарт активно использует хор. Ведущими функциями хора в опере «Волшебная флейта» являются: фоново-иллюстративная, репрезентативная и репрезентативно-динамическая. Анализ хоровых номеров в опере «Волшебная флейта» показал, что на их трактовку повлияла жсанровая природа произведения. Хору в опере «Волшебная флейта» композитор отвел роль отражения царства волшебника Зарастро. Поэтому на протяжении всей оперы появление хора является своеобразным лейтмотивом этого сказочного мира. Хоры обрисовывают общую атмосферу действия и имеют опосредованное отношение к происходящим событиям. Элементы зингшпиля дают о себе знать в использовании разговорных диалогов и народных песен с куплетным строением, в песенно-танцевальных элементах музыкальной лексики. В то же время прослежкивается связь произведения с оперой-sегіа. Об этом свидетельствует серьезность проблематики, символистическая трактовка персонажей, использование арий-амплуа (прежде всего Царицы Ночи). Таким образом, в данной опере прослежсиваются ораториальные и мистериальные черты в синтезе с оперными принципами и истоками австрийского зингшпиля.

Ключевые слова: опера-сказка «Волшебная флейта» В.А. Моцарта, трактовка хора.

Актуальність теми дослідження зумовлена потребою сучасного музикознавства поглибити дослідницький погляд на одну зі «знакових» опер В.А. Моцарта - «Чарівну флейту», в аспекті трактування хору. У наукових та методичних працях оперну творчість В.А. Моцарта розглянуто переважно в історичному, жанровому, стильовому та драматургічному ракурсах $[1-4 ; 6]$. Безумовно, такі відокремлені свідчення не дають цілісної картини щодо трактування хору в оперних творах В.А. Моцарта. Запропонована стаття за своєю проблематикою і змістом демонструє бажання автора заповнити «прогалину» у наукових розвідках щодо хорового елементу в опері.

Мета дослідження полягає у виявленні особливостей трактування хорового елементу в опері В.А. Моцарта «Чарівна флейта». Об'єктом дослідження є опера В.А. Моцарта «Чарівна флейта». Предметом, відповідно до поставленої проблеми, є трактування хору в обраній опері.

Наукова новизна представленої роботи виявляється у тому, що вперше у вітчизняному мистецтвознавстві здійснено комплексно-аналітичний аналіз із позиції специфіки трактування хору в опері-казці «Чарівна флейта» В.А. Моцарта.

Виклад основного матеріалу. Опера «Чарівна флейта» була найулюбленішим твором В.А. Моцарта. За словами І. Соллертинського, вона увійшла в історію музики як «лебедина пісня» композитора, «як твір, який із найбільшою повнотою і яскравістю розкрив його світогляд, його заповітні думки, як епілог цілого життя, як якийсь грандіозний художній заповіт <...>» [6, с. 54] (переклад авт. - О. Б.).

У «Чарівній флейті» В.А. Моцарт здійснив свою мрію - створити велику оперу рідною мовою. За всієї абстрагованості й екзотичності їі сюжету, незвичності іiі музичної драматургії, ця опера найбільш близька австрійському національному характеру, народній пісенності та традиціям австрійського демократичного театру. Дана опера відкрила дорогу до 
затвердження самостійності національної опери у країнах німецької мови. Значення опери «Чарівна флейта» як національного феномену відзначав Г. Берліоз: «Досі німецька опера нібито не існувала: цим твором вона була створена» [4, с. 223] (переклад авт. - О. Б.).

«Чарівна флейта» завершує розвиток австрійського зингшпілю у XVIII ст., водночас містить передумови німецької романтичної опери, яка зародилася на початку ХІХ ст. Цю думку влучно підкреслює М. Мугінштейтн: ««Чарівна флейта» - це оптимістичний символ епохи Просвітництва <...> Водночас «Чарівна флейта» - передромантичний настрій німецької опери, без якого не було б веберовського «Вільного стрільця» [4, с. 223] (переклад авт. - O. Б.).

Сюжет, оброблений у дусі популярних у той час народних феєрій, повних екзотичних чудес, Е. Шиканедера почерпнув у казці К. Віланда (1733-1813 рр.) «Лулу» зі збірки фантастичних поем «Джінністан, або Вибрані казки про фей і духів» (1786-1789 рр.), з доповненням із його ж казок «Лабіринт» і «Розумні хлопці». У числі додаткових джерел також називають епічну поему «Оберон, цар чарівників», з доповненнями за лібрето К.В. Хенслера $з$ опери «Свято сонця у брамінів» Венцеля Мюллера; драму «Тамос, цар єгипетський» Т.Ф. фон Геблера; роман «Сетос» Ж. Террасон (1731р.). Називають і роботу Ігнаці фон Борна, магістра масонської ложі «Про містерії єгиптян».

«Чарівна флейта» становить собою глибоку філософську казку, у музиці якої яскраво протиставляються образи світла і темряви, з геніальною психологічною проникливістю виражені почуття закоханих Таміно і Паміни; не менш яскраво окреслені простодушнокомедійні образи Папагено і Папагени - справжніх персонажів австрійсько-німецького народного театру. Так в оперній творчості В.А. Моцарта на вершині його майстерності зберігаються зв'язки з національним народним театром, а персонажі казки стають живими людьми, наділеними індивідуальними рисами. В опері соціальна утопія та фантастика перемішалися з гумором, влучними життєвими спостереженнями, соковитими побутовими штрихами. Фантастичні персонажі мають характери реальних людей.

Жанровою основою опери «Чарівна флейта» є зингшпіль, про що свідчить, по-перше, тяжіння до казковості, по-друге, літературний текст німецькою мовою, наявність двох пар персонажів (лірична лінія - принц Таміно і його кохана Паміна, комічна лінія - птахолов Папагено і його кохана Папагена). Елементи зингшпілю дають про себе знати у використанні розмовних діалогів і народних пісень із куплетною будовою, у пісенно-танцювальних елементах музичної лексики. Водночас простежується зв'язок твору з оперою-seria. Про це свідчить серйозність проблематики, символістична трактовка персонажів, використання арій-амплуа (передусім Цариці Ночі). Отже, у «Чарівній флейті» сплелись жанрові особливості зингшпілю, опери-buffa й опери-seria.

Композиція «Чарівної флейти» визначена у клавірі як дві дії і 11 картин. Хоча в загальній структурі їх 16.

Хору в опері «Чарівна флейта» композитор відвів роль показу царства чарівника Зарастро. Тому протягом усієї опери поява хору є своєрідним лейтмотивом цього казкового світу. Хори обмальовують загальну атмосферу дії, опосередковано стосуються подій, що відбуваються.

У фіналі першого акту звучить чоловічий хор слуг Моностатоса «Як дивно <... як дзвінко». Він виконується в той час, коли Папагено з Паміною вирішують втекти із царства Зарастро, але злий мавр Моностатос посилає своїх слуг наздогнати їх. У мить, коли стража наздоганяє втікачів, винахідливий Папагено негайно пускає в хід чарівні дзвіночки, весела мелодія змушує варту пуститися в танок. Хор слуг відображає другорядних героїв у гротескному ракурсі, виконує тим самим фоново-ілюстративну функцію.

Увесь комплекс засобів музичної виразності підкорений змалюванню цієї гумористичної картини і вказує на витоки народної австрійської культури, а також адресує слухача до жанрових ознак зингшпілю. Хор написаний для триголосного чоловічого складу. Теситура хору зручна: d малої - g першої октави. Голосоведіння протягом всього номеру плавне, 3 подвоєнням верхніх голосів у терцію. Куплетна форма (а - в - в 1) з рисами квадратності побудови (ознаки жанру пісенно-танцювальної музики), світла тональність $\mathrm{G}$ dur, темп Allegro, pозмір 4/4, ясна гармонія (T - S - D), прозорий супровід, де імітується гра дзвіночків, сприяють створенню граційного звучання.

Відразу після уходу слуг Моностатоса звучить марш із хором «Хай живе мудрий Зарастро навіки!». Цей хор можна віднести до репрезентативного типу, тому що він оповіщає слухачів про прихід Зарастро, який постає тут як володар своїх підданих, як справжній казковий государ. Даний хор написаний для змішаного чотириголосного складу. 
За формою - це період із двох речень (усього 16 тактів). Переважає акордова фактура, хоча частково використовуються поліфонічні прийоми (тт. 6-10). Мелодія інструментального характеру (висхідні ходи тонічного тризвуччя C dur, що починаються із квінтового тону), з підкресленим пунктирним ритмом, що і додає музиці маршового характеру.

Коли Зарастро відряджає мандрівників до жерців, щоб ті провели їх у храм для випробувань, звучить хор народу та жерців «Тут правда, тут панує любов», у якому прославляється мудрий правитель Зарастро. Цей вітальний хор замикає всю композицію першої дії, асоціюється «3 першими частинами concerti grossi i тріумфуючими Gloria мес» [4, с 155], що проявляється в єдності стилістики, тональності C dur, манері виконання, діатонічній будові й опорних точках. Із другого боку, ораторіальні прийоми, що відчутні в хорі (використання загального оркестрово-хорового складу, побудова мелодії на широких інтервалах, інтонаційно і гармонічно ясне голосоведіння), «створюють особливий драматургічний план, що пов’язаний зі смисловою атмосферою позаособистого узагальнення» [4, с. 156] (переклад авт. - O. Б.).

Хор написаний для змішаного чотириголосного складу. За формою його можна визначити як старовинну двочастну форму, де друга частина удвічі більша та відносно складніша за внутрішньою побудовою (А - 23 т., В - 46 т.). У тематичному плані вона також незвична, бо I частина складається з контрастних двох періодів, що не зовсім характерно для цієї форми взагалі. Перший період I частини складається із двох речень, де перше може трактуватися як фанфарний вступ. Підтвердженням тому є те, що мелодія будується на звуках тонічного тризвуччя із закличними квартово-секстовими ходами, хор звучить в акордовому викладенні, у зручній теситурі на нюанс f та підтримкою оркестру в єдиному маршовому ритмічному малюнку. Мелодія другого речення становить собою низхідну юбіляцію, що рухається від домінантового тону (g).

У другому періоді I частини вводиться новий тематичний матеріал, що побудований на звуках домінанти від тону (d) з октавним стрибком із середнього до верхнього регістрів (f 1 - f 2). Тему починає партія сопрано, яка підсилюється вступом хорового й оркестрового tutti. Далі ця тема передається басовій партіï, але в тональності S (F dur).

II частина починається на D 7 із подальшим розрішенням у головну тональність (C dur). У другому реченні застосовано тональне зіставлення C dur - D dur, що сприяє подальшому підняттю загального святкового настрою. Мелодія характеризується півтоновим оспівуванням основного тону $\mathrm{G}$ dur із подальшим закріпленням у головній тональності. Заключний другий період побудований на фанфарних ходах за звуками тоніки і домінанти. Закінчується хор унісоном на функціях VI, V та I щаблів. Своєю захоплюючою енергією цей хор зобов'язаний головним чином дії ввідного тону і гармоній субдомінанти і домінанти V ступеня (спершу F-dur, потім G-dur). Він продовжує відчуватися і далі, в оркестровому закінченні, де цей простий мотив раптом заблискав у положенні терції. Отже, цей тріумфальний, блискучий хор виконує репрезентативну функцію.

Друга дія - це низка випробувань героїв. Драматургічним стрижнем стає об’єднання ритуального і комічного елементів. Носіями духовності (ритуальності) виступають Зарастро і його жерці. Яскравим прикладом цього може бути арія Зарастро з хором. Хорова партія в цьому номері невелика - усього 8 тактів. Зовнішнє поєднання молитви Зарастро з хором створює релігійний відтінок. Особливість цього хору полягає в тому, що композитор упроваджує у звукову тканину тембр чоловічого хору, що звучить у нюансі піано. Плавність голосоведіння за акордово-гармонійного складу фактури робить характер звучання хору таємничим і піднесеним. Форма арії двочастинна, проте другий розділ під кінець зовсім непомітно повертається назад, до завершення першого. Г. Аберт знаходить у цій арії «добровільне релігійне визнання самого майстра. Дійсно, містична спрямованість, що зрештою відкрила Вольфгангу Амадею в масонів розуміння смерті як ключа до справжнього блаженства, виражається в ній із захоплюючою строгістю» [1, с. 334] (переклад авт. - O. Б.). Другий розділ приносить помітну схвильованість, зумовлену думками про випробування і пов'язану з ними смертельну небезпеку. Це підкреслюється модуляцією: після похмурого f-moll ще сердечніше звучить завершальне прохання Зарастро у F-dur («прийміть їх у вашій обителі»). Проте найвдаліша знахідка - те, що середні голоси хору підхоплюють останню фразу Зарастро: лише завдяки цьому його слова набувають містичної виразності. За виразом Г. Аберта, «у цей короткий рефрен Моцарт вклав більше глибини, ніж в іншу просторову хорову п'єсу» [1, с. 334] (переклад авт. - О. Б.). Ураховуючи вищеназвані особливості даного номера, хор виконує репрезентативну функцію.

Наступний хор звучить у храмі, де жерці вітають Таміно з успішним проходженням нелегкого випробування співчуттям і коханням. Урочисто, у традиціях ораторіального 
жанру, звучить хор. Він написаний для чоловічого триголосного хору. Голосоведіння плавне. У фактурі переважає акордово-гармонійний рух голосів. Терпкості гармонічній мові додають альтеровані III\# і VI\# рівні. Основний динамічний відтінок музики p. Форма хору проста тричастинна $(\mathrm{A}-\mathrm{B}-\mathrm{C})$.

Після урочистого звернення в I частині, яка побудована на тріумфальних квартово-секстових інтонаціях у сонячній тональності D dur, змінюється загальний настрій. Починається II частина. У ній гармонія змінюється на темний, субдомінантовий g-moll, що дає відчутну наочність того, що спускається пітьма. Проте відразу за допомогою раптового спалаху f i енергійної модуляції до A-dur здійснюється перехід до світла: неначе весь храм осявається променями божого сяяння (10 т.). У III частині продовжується оспівування чеснот прекрасного юнака Таміно. Воно починається в тональності домінанти (A dur) на нюансі f, мелодія підсилюється скрипками. Поряд з акордовим викладенням композитор уводить перегукування партій, що вносить діалогічність до номера. Натхненності та благородства звучання хору також додає переміщення тенорової партії у верхній регістр, динамічне зіставлення $\mathrm{f}-\mathrm{p}$, ритмічна різноплановість. Цей хор єднає в собі внутрішню емоційну насиченість із фантастичною пейзажною барвистістю, саме тому його можна віднести до декоративно-колористичного типу.

У фіналі другого акту 8 картини звучить хор народу «Привіт! 3 перемогою ви прийшли!» після вдалого проходження останнього завдання Таміни і Паміно - проходження крізь водопад. Даний номер написаний у репризній тричастинній формі (А - B - A 1). Він починається фанфарним вступом труби на перших долях такту. Далі вступає на динаміці f хор, спершу чоловіча група, а потім жіноча. Йому властива тональна єдність (C dur), ораторіальні риси (оркестрово-хорове tutti, чергування загального хорового звучання 3 перегуками окремих партій, інтонаційна та гармонічна ясність, контрастне темброве зіставлення звучання, зокрема труби та групи струнних в оркестрі тощо). II частина звучить у тональності субдомінанти (F dur), мелодія в хорі побудована на широких низхідних септових ходах. У хорі вводяться такі прийоми хорового викладення: 1) щодо тембру - спів повного і неповного $(\mathrm{A}+\mathrm{T}+\mathrm{B})$ складу, окремого голосу $(\mathrm{C}) ; 2)$ у співвідношенні хорових груп - викладення мелодії в партії сопрано, зіставлення $(\mathrm{C}-(\mathrm{A}+\mathrm{T}+\mathrm{b}))$. У III частині повертається основна тональність і варіюється ритмічно і мелодійно тематичний матеріал I частини. Реприза закінчується оркестровою кодою. Проаналізований хор вирізняється блискучим, урочистим характером, де звучання хору підтримується маршовою ритмічною фігурою в оркестрі. За драматургічною функцією він є репрезентативно-динамічним, бо, з одного боку, він відтворює картину привітання закоханих, із другого - виступає як активна діюча сила, що впливає на структуру музичного цілого.

Фінальний хор «Тільки хоробрим слава!» написаний для чотириголосного мішаного хору. За формою він $є$ тричастинним, де всі частини неповторного типу, що досить незвично для вказаної форми: (А (а-в) - В (c-d) - C (e-e1-g). Контрастність частин проявляється не тільки на тематичному рівні, а і на темповому (A - Andante ; B, C - Allegro); фактурному (як в оркестрі, так і в хорі); динамічному, ритмічному тощо. Об'єднуючою ланкою в цьому номері є тональна єдність - усі частини написані в Es dur.

Перша частина гімнічного характеру і розрахована на виконання могутнім складом. Вона починається урочистим вступом духових в оркестрі в динаміці p, на пунктирному маршовому ритмі, з подальшим вступом tutti оркестру і хору. Помпезні закличні репліки, що звучать у мішаному чотриголосному хорі, акордова фактура, звучання у високому регістрі, широке розташування голосів, повнозвучна динаміка f та підтримка оркестру з фанфарними заповненнями на паузах хору створюють загальну атмосферу святковості.

Звучання партії сопрано зі скрипками на словах «Крізь ніч шлях пройдений» на динаміці р вносить розрядження і пом'якшення звучання. Але вже в наступному реченні знов повертається урочистий характер завдяки введенню загального tutti на f. Оркестрова партія в даному епізоді вирізняється контрастною динамікою (f-p), зіставленням ритмоформулами (помірних і рухливих) та регістрами.

У II частині поряд із піднесеним, повним рішучості і бурхливої тріумфуючої енергії характером, простежуються риси хороводності. Цікаво, що основна мелодія проводиться в оркестрі, а хор епізодично підхоплює іiі тематичне зерно на кульмінаційних точках. У зв'язку із цим у хорі переважає акордово-гармонійне голосоведіння, а для мелодії характерна повторюваність звуків. Даний епізод закінчується на тріумфальному витриманому хоровому акорді в динаміці f за активної підтримки оркестрового супроводу на домінантовій функції (D 7). 
Після загальної фермати починається III частина. Порівняно із другою, основна тема імітаційно проводиться в хорі, а оркестр несе функцію супроводження. Узагалі заключна частина складається із двох протилежних образних сфер - пасторальності (е-е1) і тріумфальності (g). У перших двох реченнях композитор застосовує різні прийоми хорової фактури: 1) викладення групами хору $(\mathrm{C}+\mathrm{A} ; \mathrm{T}+\mathrm{Б}) ; 2)$ викладення мелодії в партії сопрано; 3) короткочасні виключення альтової партії із загального звучання; 4) включення хорових груп $(\mathrm{C}-\mathrm{A}-(\mathrm{T}+\mathrm{B}))$.

Третє речення повертає нас в атмосферу святковості. Хор звучить в акордовій фактурі, високому регістрі, у динаміці f, до оркестру вводяться труби та група струнних в активному, моторному ритмічному малюнку шістнадцятими тривалостями. Загальному святковому настрою сприяє висхідна призивна септова інтонація на домінанті (b 1 - as 2) з поступовим поверненням до тоніки в партії сопрано на словах «Нехай живе мудрість і розум і світ!».

Фінальний хор усієї опери «Тільки хоробрим слава!» є переможним гімном світу і добра. У даному номері В.А. Моцарт показав себе як майстер музичного живопису, де вміло використав різні форми та прийоми хорової фактури, гнучко слідуючи за змістом тексту, зумів передати засобами музичної виразності всі зміни в емоціональному настрої. За драматургічною функцією хор є репрезентативно-динамічним.

Висновки. Потрібно сказати, що В.А. Моцарт в опері-казці «Чарівна флейта» дуже активно використовує хоровий компонент як у першій, так і у другій діях. В опері хор виконує роль супроводу подій: у фіналі I акту, 5 картини, № 8: зображення несамохіть танцюючих слуг під звуки дзвіночків рабів «Як дивно <...> як дзвінко»; вітання почту Зарастро: «Хай живе мудрий Зарастро навіки!», «Тут правда, тут панує любов»; створення атмосфери ритуальності у храмі: арія Зарастро з хором (II акт, 1 картина, № 10), хор жерців «Ізіда й Озіріс» (II акт, 5 картина, № 18); вітання Таміни і Паміно з успішним подоланням завдань: хор народу «Привіт! 3 перемогою ви прийшли!» (фінал II акту, 8 картина); хор-гімн «Тільки хоробрим слава!» (фінал II акту, 11 картина).

У деяких хорових номерах композитор використовує нові і незвичайні фарби (декоративно-колористичні хори № 10 і № 18). Завдяки цьому створюється образ примарного світу богів царства Зарастро. Жартівливий хор слуг з I акту «Як дивно <...> як дзвінко», що написаний у народному дусі й адресує нас до жанру зингшпілю, виконує фоновоілюстративну функцію. Усі інші хори можна віднести до репрезентативної (хори з I акту «Хай живе мудрий Зарастро навіки!», «Тут правда, тут панує любов»; арія Зарастро з хором iз II акту) і репрезентативно-динамічної груп (II акт, 8 картина, хор «Привіт! 3 перемогою ви прийшли!», фінальний хор, 11 картина, «Тільки хоробрим слава!»), оскільки вони зв'язані з відтворенням образної сторони картини, деякою мірою впливають на перебіг драматургічної лінії.

У побудові форми хорів композитор дуже лаконічний, але стосовно гармонії потрібно сказати, що часто використовується альтерація і зменшені гармонії, завдяки чому музиці додається відома доля таємничості і примарності. Дуже цікаве темброве вирішення хорів. Саме однорідний склад чоловічого хору В.А. Моцарт використовує для створення образу царства Зарастро. Строгість стилю листа і тематична близькість до масонських і церковних наспівів робить ці хорові номери дуже образними.

Отже, аналіз хорових номерів в опері «Чарівна флейта» показав, що на їх трактування вплинула жанрова природа твору. У даній опері простежуються ораторіальні та містеріальні риси в синтезі з оперними засадами та витоками австрійського зингшпілю.

\section{СПИСОК ЛІТЕРАТУРИ}

1. Аберт Г. В.А. Моцарт. Москва : Музыка, 1990. Ч. 2. Кн. 2. 560 с.

2. Батовська О. Хоровий компонент в операх західноєвропейських композиторів XVII-XVIII ст. : навчальний посібник для студентів музичних вузів, спеціалізація «Хорове диригування». Харків, 2010. 168 с.

3. Берлянд-Черная О. Оперы Моцарта. Москва : Музыка, 1957. 180 с.

4. Іванова I., Куколь Г., Черкашина М. Історія опери: Західна Європа. XVII-XVIII ст. : навчальний посібник. Київ : Заповіт, 1998. 384 с.

5. Моцарт В.А. «Волшебная флейта» : клавир / под ред. В. Суслина. Москва : Музыка, 1971. $222 \mathrm{c}$.

6. Мугинштейн М. Хроника мировой оперы 1600-1850. Екатеринобург : У-Фактория ; при участии издательства Гуманитарного университета, 2005. 639 с.

7. Соллертинский И. Исторические этюды. Ленинград, 1963. 393 с. 


\title{
REFERENCES
}

1. Abert Gh.I. V.A. Motsart. Ch. 2. Kn. 2. M. : Muzyka, 1990. 560 s.

2. Batovsjka O.M. Khorovyj komponent $\mathrm{v}$ operakh zakhidnojevropejsjkykh kompozytoriv XVIIXVIII st. : navch. posib. dlja stud. muz. vuziv, specializacija "Khorove dyryghuvannja". Kh. : Vyd-vo Brovin O.V., 2010. 168 s.

3. Berlyand-Chernaya O.S. Opery Motsarta. M. : Muzyka, 1957. $180 \mathrm{~s}$.

4. Istoriya opery: Zapadnaya Yevropa. XVII-XVIII vek.: ucheb. pos. / I.L. Ivanova, G.V. Kukol, M.R. Cherkashina. K. : Zapovit, 1998. 384 s.

5. Motsart V.A. "Volshebnaya fleyta": klavir, pid red. V. Suslina. M.: "Muzyka", 1971. 222 s.

6. Muginshteyn M.L. Khronika mirovoy opery 1600-1850. Yekaterinoburg : U-Faktoriya pri uchastii izdatelstva Gumanitarnogo universiteta, 2005. 639 s.

7. Sollertinskiy I.I. Istoricheskie etyudy. L., 1963. 393 s.

УДК 78.071.2

DOI https://doi.org/10.31723/2524-0447-2020-30-1-19

Віола Григорівна Демидова

ORCID: 0000-0002-8757-0385

кандидат педагогічних наук, народний артист України, доцент кафедри сольного співу

Одеської національної музичної академії імені А. В. Нежданової violademidova2017@gmail.com

\section{ПРОГНОСТИЧНА ФУНКЦІЯ ПРОФЕСІЙНОЇ ДІЯЛЬНОСТІ ПІАНІСТА-КОНЦЕРТМЕЙСТЕРА У КЛАСІ ВОКАЛУ}

\begin{abstract}
Мета роботи - визначити основні показники прогностичної функції професійної діяльності піаніста-концертмейстера у вокальному класі в педагогічному аспекті. Методологію дослідження становлять методи структурно-функціонального аналізу, системний метод та міждисциплінарний підхід до вивчення музично-виконавської діяльності, а також основні положення вокальної педагогіки. Наукова новизна дослідження полягає у спеціальному підході до професійної майстерності концертмейстера в роботі зі студентами-вокалістами, спрямованому на виявлення чинника прогнозування педагогічного процесу. Прогностична функція діяльності концертмейстера розглядається в контексті ï̈ педагогічного потенціалу: як можливості особистісно орієнтованого підходу до процесу професійного навчання, емоційно-психологічної взаємодії з вокалістом, творчого діалогу у процесі музичного виконання. Висновки. Прогностичні здібності та навички є найважллиішим структурним компонентом професійної компетентності концертмейстера, за допомогою якого здійснюється багаторівнева взаємодія піаніста і вокаліста. Ця взаємодія забезпечує доцільність вирішення поставлених завдань $i$ досягнення цілей у процесі навчання студентів, успішність концертної практики. Здатність до прогнозування виражається на таких рівнях діяльності концертмейстера: розумовому (аналітичність, усвідомленість, гнучкість і перспективність мислення), емоційно-психологічному (емоційна чуйність $i$ мобільність психічних реакцій), вербальному (адекватне словесне оформлення цілей $і$ завдань), практично-дієвому (створення ситуативного комплексу). Прогностична функція діяльності концертмейстера $\epsilon$ спеціальним системним явищем, яке орієнтоване на досягнення «художнього результату».

Ключові слова: концертмейстер, вокаліст, професійна діяльність, прогностична функція, психологія прогнозування, педагогічний процес, творчий процес.

Demidova Viola Hryhorivna, Ph. D. in Pedagogical Sciences, People's Artist of Ukraine, Assistant Professor at the Department of Solo Singing of the Odessa National A. V. Nezhdanova Academy of Music

The prognostic function of the professional activity of a pianist-accompanist in a vocal class

Research objective of the study is to determine the main indicators of the prognostic function of professional activity of the pianist-concertmaster in the vocal class in the pedagogical aspect. The methodology of the study is the methods of structural and functional analysis, systemic method and interdisciplinary approach to the study of music and performance, as well as the main provisions of vocal pedagogy. The scientific novelty of the study is a special approach to the professional skill of the concertmaster in working with vocal students, aimed at identifying the predictor of the pedagogical process. The prognostic function of the concertmaster's activity is considered
\end{abstract}

